\title{
Partial Characterization of Extracellular $\alpha$-Amylase from Three Bacillus Isolates
}

\author{
Arifa Nusrat and Sabita Rezwana Rahman* \\ Department of Microbiology, University of Dhaka, Dhaka 1000, Bangladesh
}

[Received 22 November 2007; Accepted 14 June 2008]

\begin{abstract}
$\alpha$-Amylase produced by three Bacillus isolates had been compared on the basis of the following criteria: heat and $\mathrm{pH}$ effects on activity and stability, effect of metal ions on enzyme activity and kinetic parameters. The culture filtrates obtained by growing the organisms in starch medium were fractionated by ammonium sulphate precipitation technique, and the highest enzyme activities were recovered from $70 \%$ saturation fraction. The enzyme from Bacillus amyloliquefaciens showed optimum activity at $60^{\circ} \mathrm{C}$, while $B$. subtilis and another Bacillus isolate at lower $\left(55^{\circ} \mathrm{C}\right)$ temperature. The $\mathrm{pH}$ optima of the enzymes from all sources were between 6.5 and 7.0 with an optimum reaction time of 10 to $15 \mathrm{~min}$. $\alpha$-Amylases were moderately thermostable exhibiting almost full activities at $50^{\circ} \mathrm{C}$ for at least $20 \mathrm{~min}$. The enzyme from all sources showed stability over a wide range of $\mathrm{pH}(4.0-8.5)$. The apparent $K_{\mathrm{m}}$ values on soluble starch varied between $1.6 \mathrm{mg} / \mathrm{ml}$ in case of $B$. amyloliquefaciens and $2.5 \mathrm{mg} / \mathrm{ml}$ in case of $B$. subtilis. Metal ions like $\mathrm{Mg}^{2+}$ and $\mathrm{Mn}^{2+}$ seemed to have positive influence on the enzyme activities of $B$. subtilis and Bacillus sp. The enzyme activities from three isolates were strongly inhibited by $\mathrm{Cu}^{2+}, \mathrm{Hg}^{2+}$ and $\mathrm{Zn}^{2+}$.
\end{abstract}

Key words: Extracellular $\alpha$-amylase, Bacillus spp., Enzyme characterization

$\alpha$-Amylases are group of enzymes classified as hydrolases that catalyze the hydrolysis of ortho-glycosyl compounds of starch and glycogen. They catalyze the hydrolysis of starchy materials into smaller glucose subunits that in turn are acted upon by other amylases to produce glucose ${ }^{1}$. Amylases, starch-degrading enzymes, have numerous biotechnological applications. These enzymes are used in textile and garments, paper industries, starch liquefaction, food, adhesive and sugar production and pharmaceuticals ${ }^{2}$.

Enzymatic degradation of starch on an industrial scale has been practiced for many years and has replaced to a considerable extent the traditional acid-catalyzed processes ${ }^{3}$. Enzymatic processes now produce, over $75 \%$ of syrup and solid dextrose in the USA. New developments have taken place in the area of starchdegrading enzymes. Enzymes have several advantages. First, the specificity of enzymes allows the production of sugar syrups with well-defined physical and chemical properties. Second, the milder enzymatic hydrolysis results in few side reactions and less browning ${ }^{4}$.

Because of the commercial and industrial uses, $\alpha$-amylases from many sources has been studied in great detail. The genus Bacillus is the single most important bacterial source of this enzyme. Due to the thermostability of the enzyme produced by genus Bacillus, they have commercial significance ${ }^{4}$. We have previously reported that three Bacillus isolates could produce appreciable amount of $\alpha$-amylase in submerged culture ${ }^{5}$. The present article reports the partial purification and characterization of $\alpha$-amylases of the three Bacillus isolates.

B. subtilis, B. amyloliquefaciens and another Bacillus isolate were grown in the medium containing $1.0 \%$ starch, $0.5 \%$ peptone, $0.5 \%$ corn steep liquor, $0.8 \%\left(\mathrm{NH}_{4}\right)_{2} \mathrm{SO}_{4}, 0.2 \% \mathrm{MgSO}_{4} .7 \mathrm{H}_{2} \mathrm{O}$, $0.05 \% \mathrm{CaCl}_{2} \cdot 2 \mathrm{H}_{2} \mathrm{O}, 1.4 \% \mathrm{~K}_{2} \mathrm{HPO}_{4}$ and $0.6 \% \mathrm{KH}_{2} \mathrm{PO}_{4}$ with an initial $\mathrm{pH} 7.0^{6}$. Shake-flask cultures were carried out in 250-ml Erlenmeyer flasks at $37^{\circ} \mathrm{C}$ for at least $72 \mathrm{~h}$ with continuous shaking ( $150 \mathrm{rpm}$ ) in an orbital shaker incubator. Extracellular $\alpha$-amylases were removed by centrifugation and the enzyme activity was measured in the cell-free supernatant essentially as described by Gomes et al. ${ }^{7}$. The reducing sugar released was determined by the method of Miller ${ }^{8}$. One unit (U) of enzyme activity was defined in all cases as the amount of enzyme releasing $1 \mu \mathrm{mol}$ of glucose or glucose equivalents from the substrate per min under the assay conditions.

For partial purification of the enzyme, the soluble protein contents of the culture supernatants were precipitated by stepwise addition of solid ammonium sulphate to $100 \%$ saturation. For temperature optima, the partially purified enzymes were assayed at different temperatures between 30 and $80^{\circ} \mathrm{C}$ with standard incubation time. The activity vs. $\mathrm{pH}$ profile was determined according to standard assay procedure at various $\mathrm{pH}$ values using $0.05 \mathrm{M}$ citrate buffer (pH 4.0-6.0), $0.05 \mathrm{M}$ phosphate buffer (pH 6.5-8.5) and $0.05 \mathrm{M}$ Tris-HCl buffer (pH 9.0-10.0). Thermostability experiments were

*Corresponding author:

Dr. Sabita Rezwana Rahman, Associate Professor, Department of Microbiology, University of Dhaka, Dhaka 1000, Bangladesh

Tel (Office): (02) 9661920-73, Ext 7746; Tel (Home): (02) 9351014; Fax: +880 (02) 8615583; E-mail: sabita_rahman@hotmail.com 
performed by incubating the enzyme preparation in $0.5 \mathrm{M}$ phosphate buffer $(\mathrm{pH} 7.0)$ at various temperatures $\left(4-100^{\circ}\right)$ for $20 \mathrm{~min}$. For determination of $\mathrm{pH}$ stability of $\alpha$-amylase, the enzyme preparation in various $\mathrm{pH}$ buffers were incubated at $4^{\circ} \mathrm{C}$ for $24 \mathrm{~h}$, and thereafter the residual activities were measured by standard procedure. For kinetic analysis, the $\alpha$-amylase activity was assayed using various substrate (soluble starch) concentrations $(0.5-6.0 \mathrm{mg} / \mathrm{ml})$ under standard assay conditions. The enzyme kinetic parameters, namely $\mathrm{K}_{\mathrm{m}}$ and $\mathrm{V}_{\text {max }}$, were derived by the method of Lineweaver and Burk ${ }^{9}$ using double reciprocal plot. The apparent $\mathrm{K}_{\mathrm{m}}$ of $\alpha$-amylase was expressed as $\mathrm{mg} / \mathrm{ml}$ and the $\mathrm{V}_{\max }$ of the enzyme as $\mathrm{U} / \mathrm{mg}$ protein. The effect of various metal ions on the enzyme activity was measured by incubation the enzyme preparation at $4^{\circ} \mathrm{C}$ and $\mathrm{pH} 7.0$ for $1 \mathrm{~h}$ in the presence of various chemicals at $5 \mathrm{mM}$ concentration. The residual activities were measured by standard procedure.

$\alpha$-Amylase produced by the three Bacillus isolates was partially purified by ammonium sulphate fractionation. Total soluble protein as well as $\alpha$-amylase activity were obtained in $70 \%$ ammonium sulphate saturation fraction. Similar result was also reported for $\alpha$-amylase produced by Streptomyces chattanoogensis ${ }^{10}$. The enzyme was assayed at different temperatures $\left(30-80^{\circ} \mathrm{C}\right), \mathrm{pH}(4.0-$ 10.0) and reaction time (5-60 $\mathrm{min}$ ) and the results are summarized in Table 1 . The optimum temperatures for $\alpha$-amylase were $60^{\circ} \mathrm{C}$ in case of B. amyloliquefaciens and $55^{\circ} \mathrm{C}$ in case of B. subtilis and Bacillus sp. The enzyme activity drastically decreased with the increase of temperature from their optimum temperatures that indicates a rapid inactivation of enzyme. These findings were in accordance to that reported by other investigators on $\alpha$-amylases from different Bacillus strains ${ }^{4}$. In another study, the optimum temperature of $\alpha$-amylase from yeast, Saccharomyces cerevisiae, was found to be $50^{\circ} \mathrm{C}^{11}$. All the assayed activity had an optimum near neural $\mathrm{pH}$ (6.5-7.0). The maximum $\alpha$-amylase activity of B. subtitis and Bacillus sp. was obtained after 15 min incubation, while the optimum reaction time for the enzyme from B. amyloliquefaciens was shorter ( $10 \mathrm{~min})$. Sarikaya ${ }^{6}$ also reported maximum $\alpha$-amylase activity of Bacillus subtilis and Bacillus amyloliquefaciens after 10 min incubation.

Table 1. Optimum temperature, $p H$ and reaction time of extracellular $\alpha$-amylase from three Bacillus isolates

\begin{tabular}{lccc}
\hline Reaction & \multicolumn{3}{c}{ Optimum activity } \\
\cline { 2 - 4 } condition & B. subtilis & B. amyloliquefaciens & Bacillus sp. \\
\hline Temperature $\left({ }^{\circ} \mathrm{C}\right)$ & 55 & 60 & 55 \\
p H & 7.0 & 6.5 & 6.5 \\
Time (min) & 15 & 10 & 15 \\
\hline
\end{tabular}

High thermal stability of enzymes is a desired property for the use an enzyme in industrial processes. $\alpha$-Amylase from $B$. subtilis and Bacillus sp. was completely stable at $50^{\circ} \mathrm{C}$ for at least $20 \mathrm{~min}$ (Figure 1). The enzyme from B. amyloliquefaciens was more stable than the enzyme from two other isolates, exhibiting $100 \%$ of the original activity after exposure at $60^{\circ} \mathrm{C}$ for $20 \mathrm{~min}$. These indicate that $\alpha$-amylases from the Bacillus isolates was fairly thermostable, as was also reported by other investigators ${ }^{12}$.

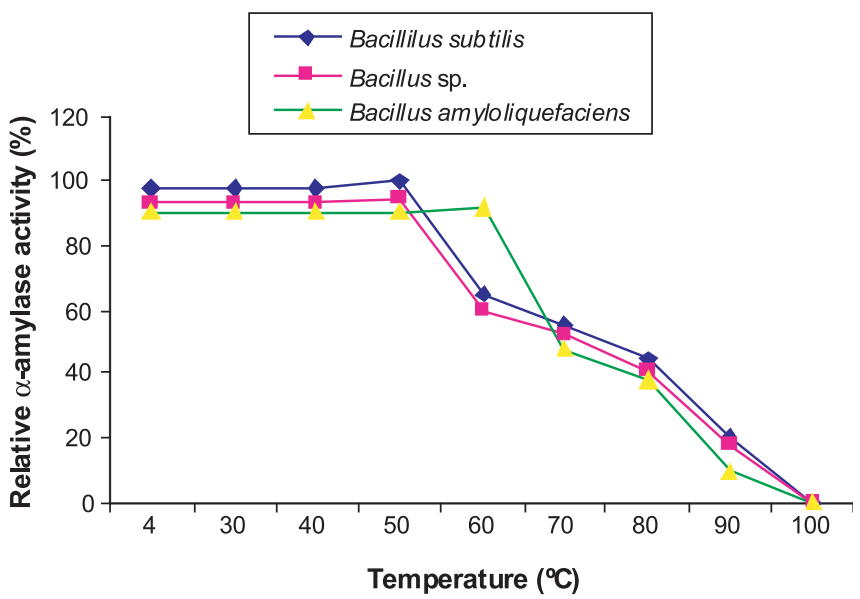

Figure 1. Thermal stability of extracellular $\alpha$-amylase from three Bacillus isolates.

The wide range of $\mathrm{pH}$ stability might be an advantage of handling and preserving the enzyme in industrial and commercial purposes. In the present study, the extracellular $\alpha$-amylase from the three Bacillus isolates inhibited nearly or more than $80 \%$ of the original activity over a wide range of $\mathrm{pH}$ (4.0-8.5) (Figure 2). Similar $\mathrm{pH}$ stability for $\alpha$-amylase from Bacillus licheniformis was repoted by Saito ${ }^{13}$.

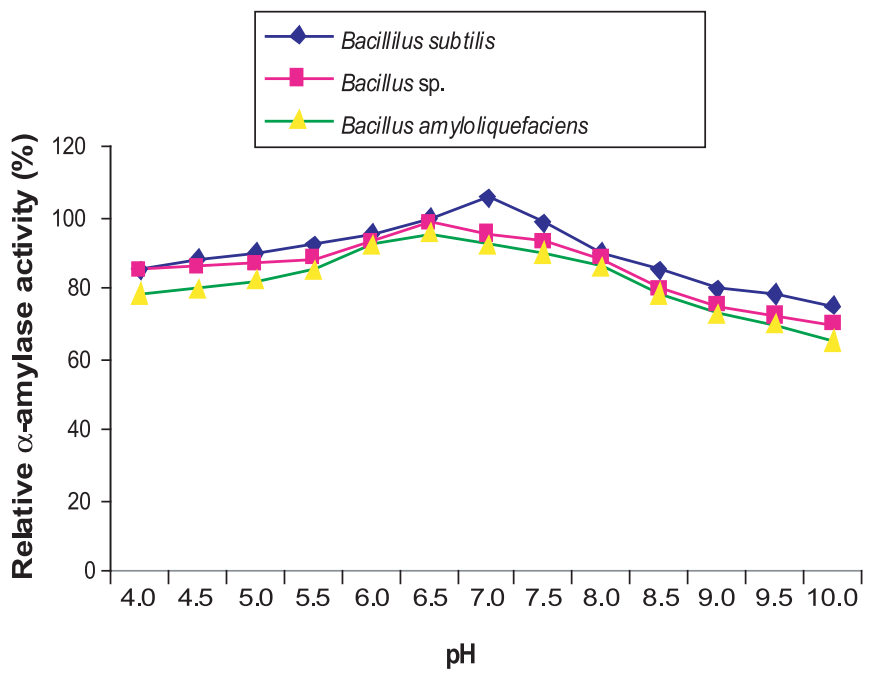

Figure 2. $p H$ stability of extracellular $\alpha$-amylase from three Bacillus isolates.

For kinetic analysis, $\alpha$-amylase activity was measured at various starch concentrations $(0.5-6.0 \mathrm{mg} / \mathrm{ml})$. The enzyme kinetic parameters, namely $\mathrm{K}_{\mathrm{m}}$ (Michaelis-Menten constant) and $\mathrm{V}_{\text {max }}$, were derived from Lineweaver-Burk double reciprocal plot. The $\mathrm{V}_{\text {max }}$ values of partially purified $\alpha$-amylase from $B$. subtilis, B. amyloliquefaciens and Bacillus sp. were 20.00, 14.28 and 16.66 $\mathrm{U} / \mathrm{mg}$ protein respectively. The apparent $\mathrm{K}_{\mathrm{m}}$ of $\alpha$-amylases from 
B. subtilis, B. amyloliquefaciens and Bacillus sp. were 2.5, 1.6 and $2.0 \mathrm{mg} / \mathrm{ml}$ respectively. In a study, $\mathrm{K}_{\mathrm{m}}$ and $\mathrm{V}_{\max }$ values of $\alpha$-amylase from Saccharomycopsis fibuliger have been reported to be $1.37 \mathrm{mg} / \mathrm{ml}$ and $1.2 \mathrm{mg} / \mathrm{ml} / \mathrm{min}$ using starch ${ }^{14}$.

Effect of different metal ions ( $5 \mathrm{mM}$ ) on $\alpha$-amylase activity was tested and the results are depicted in Figure 3 . $\alpha$-Amylase activity from $B$. subtilis was enhanced to some degree in the presence of $\mathrm{Ca}^{2+}, \mathrm{Mg}^{2+}$ and $\mathrm{Mn}^{2+}$ ions, while the activity was remarkable decreased in the presence of $\mathrm{Cu}^{2+}, \mathrm{Ag}^{2+}$ and $\mathrm{Zn}^{2+}$ ions. The enzyme activity from Bacillus sp. was slightly increased in the presence of $\mathrm{Mg}^{2+}$ and $\mathrm{Mn}^{2+}$ ions, while the activity was highly inhibited in the presence of $\mathrm{Cu}^{2+}, \mathrm{Ag}^{2+}$ and $\mathrm{Zn}^{2+}$ ions. All the metal ions, except $\mathrm{Mn}^{2+}$, exhibited severe inhibitory effect on the enzyme from B. amyloliquefaciens.

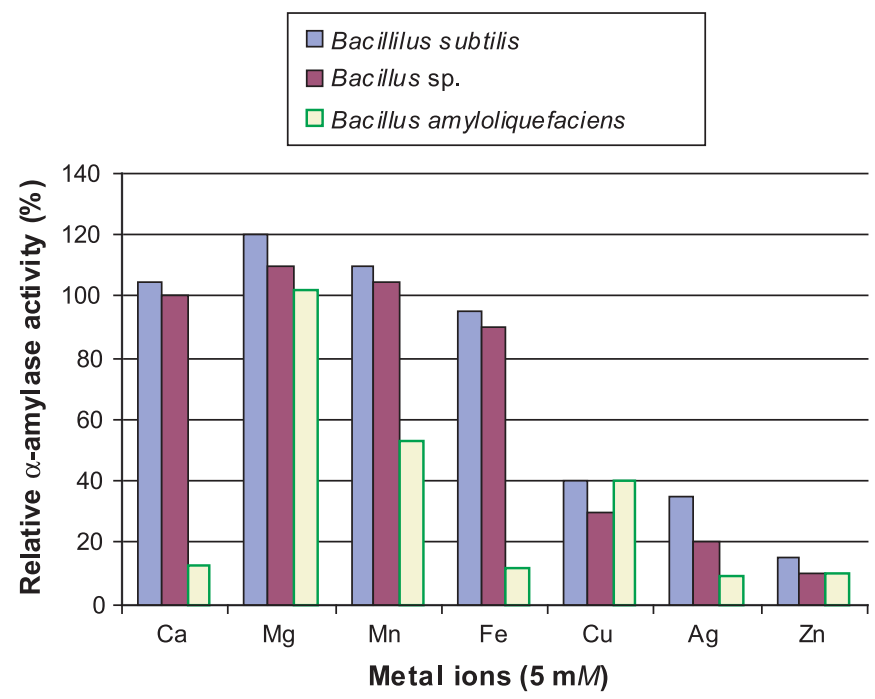

Figure 3. Effects of metal ions on extracellular $\alpha$-amylase activity from three Bacillus isolates.

In view of the results obtained in this study, Bacillus isolates appear to be good sources of $\alpha$-amylase with regard to temperature and $\mathrm{pH}$ effects. Little differences in $\mathrm{pH}$ stability were found among the $\alpha$-amylases produced by the three isolates. However, a remarkable thermal stability of the enzyme was found for B. amyloliquefaciens. Metal ions such as $\mathrm{Ca}^{2+}, \mathrm{Mn}^{2+}$ and $\mathrm{Fe}^{2+}$ had little or no influence on the enzymes from $B$. subtilis and
Bacillus sp., but they exhibited strong inhibitory effect on the enzyme from B. amyloliquefaciens.

\section{References}

1. Espino TM, Tambalo RD \& Elegodo FB. 1996. Microbial production of $\alpha$-amylase for food and other industrial applications. IC Biotech. 19: 669-677.

2. Bajpai P \& Bajpai PK. 1989. High temperature alkaline $\alpha$-amylase from Bacillus licheniformis TCRDC-B13. Biotechnol Bioeng. 33: 72-78.

3. Bradford MM. 1976. A rapid and sensitive method for the quantification of protein utilizing the principle of protein-dye binding. Anal Biochem. 72: $248-254$.

4. Fogarty WM. 1983. Microbial amylases. In Microbial Enzymes and Biotechnology (Fogarty WM ed), pp 1-92. Applied Science Publishers Ltd, London.

5. Nusrat A \& Rahman SR. 2007. Comparative studies on the production of extracellular $\alpha$-amylase by three mesophilic Bacillus isolates. Bangladesh J Microbiol. 24(2): 1219-132.

6. Sarikaya E. 2000. Increase of the a- amylase yield by some Bacillus strains. Turk J Biol. 24: 299-308.

7. Gomes I, Sultana M, Uddin K, Gomes J, Steiner W \& Gomes DJ. 2001. Nutrient composition and fermentation conditions for $\alpha$-amylase production by Bacillus amyloliquefaciens. Bangladesh J Microbiol. 18(2): 141-150.

8. Miller GL. 1959. Use of dinitrosalisylic acid reagent for determination of reducing sugar. Anal Chem. 31: 426-428.

9. Lineweaver H \& Burk D. 1934. Determination of enzyme dissociation constants. J Am Chem Soc. 56: 658-666.

10. Hoque MM, Mahmud A, Khan MR, Nahar N \& Khan ZUM. 2006. Some properties of extracellular $\alpha$-amylase produced from Streptomyces chattanoogensis. Bangladesh J Microbiol. 23(1): 7880 .

11. Matsui I, Matsui E, Ishikawa K, Miyairi S \& Honda K. 1990. The enzymatic and molecular characterization of $\alpha$-amylase selected from Saccharomyces cerevisiae. Agric Biol Chem. 54(8): 2009-2015.

12. Weemaes C, Cordt SD, Goossens K, Ludikhuyze L, Hendrickx M, Heremans K \& Tobback P. 1996. High pressure, thermal and combined pressure-temperature stabilities of $\alpha$-amylases from Bacillus species. Biotechnol Bioeng. 50: 49-56.

13. Saito N. 1973. A thermophilic extracellular $\alpha$-amylase from Bacillus Licheniformis. Arch Biochem Biophys. 155: 290-298.

14. Steverson EM, Korus RA, Admassu W \& Heimsch RC. 1984. Kinetics of the $\alpha$-amylase system of Saccharomycosis fibuliger. Enzyme Microb Technol. 6: 549-554. 